\title{
A Basic Study on the Maritime Performing Party System and the Difference between the Maritime System and China's system
}

\author{
*Liu Xiaoxian, **Chang-Kyun Noh \\ * Graduate School of Marine Transportation System, Mokpo National Maritime University, Mokpo 530-729, Korea \\ **Associate Professor, Department of Marine Transportation System, Mokpo National Maritime University, Mokpo 530-729, Korea
}

\begin{abstract}
United Nations Convention on Contracts for the International Carriage of Goods Wholly or Partly by Sea" was passed in July 3, 2008. on September 23, 2009 signing ceremony was held in Rotterdam. The system of maritime performing party is a special system in the transport convention, and constitutes an integral part of the Convention. Maritime performing party system is not the first system which brings in the carrier's independent contractor, but it is the most comprehensive and thorough one. It unified the duty of carrier's independent contractor in the maritime segment, and it is also an important progress in the developing process of international maritime legal system.There are some differences between the maritime performing party and China's current related system, i.e, the port maritime performing party and the intermediate performing party are included in the maritime performing party, and they can enjoy the carrier's exception clause and limitation of liability.
\end{abstract}

Key words : Maritime performing party, UNCITRAL, The transportation convention, The carrier, China Maritime Code

\section{Introduction}

New Convention ${ }^{1)}$ is reformed in many aspects compared with the existing "Hague Rules", "The Hague -Visby Rules" and the "Hamburg Rules", in which the maritime performing party system will adjust the maritime performing party who participates in the maritime section obligation in the greatest extent into the convention. Thus it not only stablished a substantial compensation rules for the maritime performing party but also provided joint liability between the carrier and the maritime performing party. The establishment of a maritime performing party system not only breaks through the relevant traditional systems and theories, but also has practical significance in solving the responsibility of port operators. Maritime performing party system is different from the existing conventions and domestic law system, and it is also different from the relevant system of maritime law in China.

This paper will suggest that the main differences between the maritime performing party system and china's current related system.

\section{Overview of the Maritime Performing Party}

\subsection{The concept of maritime performing party}

Since 2002, Working Group III of UNCITRAL (United Nations Commission on International Trade Law) held twice meetings every year to discuss the preliminary draft in New York and Vienna. By April 2008, the third working group had held twenty-one sessions. At the meeting, through constant controversy and revision, the Working Group made an agreement on the concept of performing party (divided into maritime and non-maritime performing party) and maritime performing party.

Article 1, paragraph $6^{2)}$ provides the definition of "performing party" and it is a new concept designed by the "Convention". The performing party must have the following characteristics: Firstly, it is not a carrier, and not only does not have transport contract relationship with the owner of the goods (including the shipper, the documentary shipper, the controlling party and the consignee), but also is not employed or commissioned by the owner of the goods. Secondly, the activities that it is engaged in must be the

\footnotetext{
* connie.xx.liu@gmail.com 061)240-7172

**cknoh@mmu.ac.kr 061)240-7172

1) It is also known as the "Rotterdam Rule", as the signing ceremony was held in Rotterdam, Holland.

2) Article 1, paragraph 6 of the "Convention" : "performing party" means a person other than the cairier that performs or undertakes to perform any of the carrier's obligations under a contract of cairriage with respect to the receipt, loading, handling, stowage, carriage, care, unloading or delivery of the goods, to the extent that such person acts, either directly or indirectly, at the carrier's request or under the carrier's supervision or control."
} 
core business including receiving, loading, handling, stacking, transport, care, discharge or delivery. Thirdly, the performing party directly or indirectly engages in the above-mentioned business under the carrier's supervision or control.

Article 1, paragraph $7^{3)}$ provides for the "maritime performing party" definition which is a subordinate concept of performing party. The Convention only governs the maritime performing party which is included in the performing party, but not the rights and obligations of non-maritime performing party. Maritime performing party is defined by a geo- $^{-}$ graphic standard, namely, it is the performing party who performs or undertakes to perform the carrier's obligations to the performing party. Its extension includes the port operator, port of loading and unloading company and port operator engaged in the transport of goods and so on.

But it must be noted that the inland carrier can have the legal status of a maritime performing party only when all services it performs or undertakes to perform are in the port. In other words, if only part of the carrier's business is located in port, it can not become the performing party and be governed by the Convention. Here the "inland carrier" covers road, rail and inland waterway transport carrier.

\subsection{The main content of the maritime performing party system}

Construction of the maritime performing party system is combined with the carrier system and it mainly includes two aspects:

On the one hand, Article 19, paragraph 1: " A maritime performing party is subject to the obligations and liabilities imposed on the carrier under this Convention and is entitled to the carrier's defences and limits of liability as provided for in this Convention if: (a) The maritime performing party received the goods for carriage in a Contracting State, or $\mathrm{de}^{-}$ livered then in a Contracting State, or performed its activities with respect to the goods in a port in a Contracting State; and (b) The occurrence that caused the loss, damage or delay took place; (i) during the period between the arrival of the goods at the port of loading of the ship and their $\mathrm{de}^{-}$ parture from the port of discharge from the ship; (ii) while the maritime performing party had custody of the goods; or (iii) at any other time to the extent that it was participating in the performance of any of the activities contemplated by the contract of carriage." This is a general requirement that the maritime performing party assumes the same obligations and liabilities with the carrier. At the same time the maritime performing party is entitled to have the same defenses and limits of liability as the carrier. In fact, the maritime performing party usually engages in different business, not all of maritime performing parties must bear all the obligations under the carrier, such as port maritime performing party does not need to bear the obligation of seaworthiness, and exemption from marine fire is not apply to the port maritime performing party either.

On the other hand, article 20 of the "joint and several liability" provision: (a) If the carrier and one or more maritime performing parties are liable for the loss of, damage to, or delay in delivery of the goods, their liability is joint and several but only up to the limits provided for under this Convention. (b) Without prejudice to article 61, the aggregate liability of all such persons shall not exceed the overall limits of liability under this Convention. It is another important provision that the maritime performing party and carrier should undertake the joint and several liabilities within the provision of the Convention. If the cargo is damaged or $\mathrm{de}^{-}$ layed during the period that the maritime performing party is in charge of the goods or disposing of the goods, the cargo obligee can request the maritime performing party or the carrier to undertake the joint liability.

\subsection{Characteristics of the maritime performing party}

The Convention belongs to the shipping convention on the nature, and the carrier and the maritime performing party will be adjusted into it. In order to avoid conflict of laws, Convention does not provide substantive rules for the non-maritime performing party who does not have the characteristics of marine transport. Non-maritime performing party may be applied to other conventions or domestic law. Therefore, the most important function of the concept of maritime performing party is to identify the maritime performing party from the performing party. The maritime performing party has the following four characteristics.

2.3.1 Between the Port of Loading and the Port of Discharge.

Firstly, the maritime performing party performs or under-

3) Ariticle 1 paragraph 7 of the "Convention": "Maritime performing party" means a performing party to the extent that it performs or undertakes to perform any of the cairrier's obligations during the period between the arrival of the goods at the port of loading of a ship and their departure from the port of discharge of a ship. An inland carrier is a maritime performing party only if it performs or undertakes to perform its services exclusively within a port area. 
takes to perform carrier's obligation between the period of cargo ship reaching the port of loading and leaving the port of discharge.

Secondly, in the transshipment case, it is not the maritime performing party who performs any carrier's obligations between the period of cargo leaving an inland port and arriving at another inland loading port.

Thirdly, only the inland carrier who performs or undertakes to perform the services entirely in the harbor district can be the maritime performing party. For example, the short-hauling container truck transporter is the maritime performing party, but the rail transporter who undertakes to load and transport the cargo is not.

Although it is simple and easy to identify out maritime performing party from performing party by the geographical classification method, but it still has shortcomings. On the one hand, since the definition does not take the port function into account which may lead to unfair treatment to the performing party who takes the carrier's obligations in the outside of the harbor. For example, some ports are small and populous, so some container yards are moved to the inland. When cargo damage occurred, it is applied to the maritime performing party provisions if the container yard is in the harbor, but it is applied to the "Civil Law" or "Contract Law" if the container yard is out of the harbor. It is unfair for the ones who work in container yard as they do the same business. On the other hand, the Convention adopts a geographical classification method, but it is difficult to identify where the port is and where the port area is. The differences in understanding the port and the port area will bring uncertainty in indentifying the maritime performing party.

2.3.2. The activities that the maritime performing party engages in are related to the carrier's contractual obligations

There are a lot of people engaged in the transport of goods by sea between the loading port and the discharge port, but they are not all maritime performing party. For example, there are a variety of definitions about the port operator under China's laws and regulations. In the article 3 of "Port Operation and Management Regulations", it explicates the port operator's major port operations by listing. These services are all about sea cargo transport business, but all those engaged in such businesses are not all maritime performing party. Therefore, it is only who can satisfy the requirement in Article 13 of the Convention can be recognized as the maritime performing party. That is, they do not belong to maritime performing party, if they engage in activ- ities which are not related to receiving, loading, handling, stowage, transport, care, discharge or delivery of goods, even if they do business in the port and have the contractual relationship with the carrier.

2.3.3. Maritime performing party has a directly or indirectly contractual relationship with the carrier.

From the contractual relationship point of view, the carrier subcontracts the contractual obligation to the performing party. Maritime performing party includes the ones who perform or commit to perform the contract obligations, the carrier's sub-contractor and sub-contractor's sub-contractor. The contract chain has been extended until the actual contract obligation operator. All the people in this series belong to the maritime performing party including the intermediate carrier. Maritime performing party fulfills the carrier's contractual obligations through the uninterrupted contract chain, and the carrier also controls the maritime performing party through the continuous contract chain. In this way, contract of carriage of goods by sea can be fulfilled. Therefore, the performing party who do not have a direct or indirect contract relationship with the carrier is not the maritime performing party. This is to say that the contract chain between the maritime performing party and the carrier cannot be interrupted.

2.3.4. It does not include any people who are not entrusted by the carrier.

In the Convention concept, any person is excluded who is appointed directly or indirectly by the shipper, the documentary shipper, consignor, the controlling party or the consignee. Although they undertake ocean carrier's obligations, they do not accept the commission directly from the carrier. If they are identified as the maritime performing party, it will cause confusions on the legal relationship, so they are excluded.

\section{The differences between China's current related system and the maritime performing party system}

China Maritime Law's provisions about the carrier's independent contractor including two parts: one is about the legalization content of the "Himalaya Clause". The other one is the provisions about the actual carrier system.

Article 58, paragraph 2 provides that the carrier's servant or agent can enjoy the carrier's defenses right and limitation 
A Basic Study on the Maritime Performing Party System and the Difference between the Maritime System and China's system

of liability when they are sued by the goods power side Article 59, paragraph 2 provides the conditions that the carrier's servants or agents will lose the right of limitation of liability. China's "Maritime Law" Article 42 provides for the definitions of carrier and actual carrier, of which "Carrier" means the person by whom or in whose name a contract of carriage of goods by sea has been concluded with a shipper. "Actual carrier" means the person to whom the performance of carriage of goods, or of part of the carriage, has been entrusted by the carrier, and includes any other person to whom such performance has been entrusted under a sub-contract. "China Maritime Code", Article 42 defines the scope of the actual carrier. Article 60 to article 65 stipulates the liability of the actual carrier and the relationship between the carrier's liability and the actual carrier's liability. From the above provisions of "China Maritime Law", we can see the differences between the carrier's independent contractor and the maritime performing party as follows.

\subsection{The adjustment range of maritime performing party is much wider.}

The name of the Convention is "United nations convention on contracts for the international carriage of goods wholly or partly by sea", and its scope is "door to door". Period of carrier's responsibility is from receipt of goods to delivery of goods. According to the current contents of the Convention, Maritime performing party includes all the servants, agents and independent contractors who commit to fulfill or have already fulfilled the carrier's obligation between the shipping port and discharge port. "China Maritime Code", Article 46, the period of carrier's responsibility can be separated into two cases: The period of carrier's responsibility for the containerized goods refers to the whole period from receiving goods at the port of delivery to discharging the goods at the port of discharge, and in the mean time, the carrier is in charge of the goods. The carrier's responsibility period for non-containerized goods refers to the whole period from the goods loaded in the ship at the port of delivery to discharged from the ship at the port of discharge, and the goods are in the charge of the carrier in this period. The adjustment scope of the related provisions in "China Maritime Code" is only equivalent to the scope of the actual maritime performing party, the sea maritime performing party and the carrier's servants or agents, and it cannot include of the port maritime performing party who commit the carrier's obligation in the port and the intermediate maritime performing party who claimed to undertake the carrier's obligation but actually does not perform.

\subsection{The maritime performing party system clearly and directly adjusts the carrier's independent contractor.}

All the carrier's independent contractors from port to port is defined to be maritime performing party in the Convention, therefore, their legal status in the Convention are cleared. Then, it is provided that the maritime performing party is applicable to the carrier's rights, duties and responsibilities under the Convention, and the carrier and the maritime performing party should undertake joint and several liabilities according to the provisions in the Convention. However, China's provisions divide the independent contractors to be two parts. The part belonging to the actual carrier is adjusted by the actual carrier system (article 60 to 65) which is a direct adjustment but too narrow. Except from the actual carrier, the carrier's servant and agent only can invoke the "Himalaya clause" provision (article 58, paragraph 2) which belongs to indirect adjustment.

\subsection{The accountabilities between carrier and independent contractor are different.}

In the maritime performing party system, it is the mandatory provision but cannot be ruled out by the contract that the carrier should be responsible for the maritime performing party. However, the carrier can exclude his responsibility to the maritime performing party by the contract. Article 60 paragraph 2," Notwithstanding the provisions of the preceding paragraph, where a contract of carriage by sea provides explicitly that a specified part of the carriage covered by the said contract is to be performed by a named actual carrier other than the carrier, the contract may nevertheless provide that the carrier shall not be liable for the loss, damage or delay in delivery arising from an occurrence which takes place while the goods are in the charge of the actual carrier during such part of the carriage." This provision is different from the maritime performing party system in the Convention and it is not inconsistent with the purposes of the Convention which would like to increase the protection for the cargo obligee.

The carrier and the maritime performing party should undertake the joint and several liabilities under the maritime performing party system, and their liabilities have identity. And "China Maritime Code" although provides the joint and several liability between the carrier and the actual carrier, but sometimes the duties are not same. 


\section{Conclusions and future research topics}

From this, it can be seen that the liabilities of the actual carrier and maritime performing party are similar, but there are still diferences between them: firstly, in maritime performing party system, the "Himalaya clause" is not only applied to the carrier and the agent or servant of the carrier, but also applied to other separate contractors. As the actual carriers must be the person who actually have taken wholly or part of the transportation, maritime performing party includes the person who promised to take the tranport $\mathrm{re}^{-}$ sponsbilities but actually did not, i.e., the intermediate maritime performing party. Secondly, in maritime performing party system, the independent contractors, such as the port maritime performing party, can enjoy carrier's exception clause and limitation of liability.

Based on this paper, I want to do the further research about how to establish China performing party system in the next paper. It will include the present problems existing in China's relevant laws and regulations(the disputes of "Himalaya Clause" provisions in the judicial practice, dispute of the actual carrier system), the difficulties in constructing China's maritime performing party system(the limitation of liability of the port operator, problems about the intermediate maritime performing party), and the strategy in constructing maritime performing party in China.

\section{References}

[1] Christopher Hill, Maritime Law(fifth edition), Bodmin, Gornwall, 1998, p.106.

[2] "Civil Law of People's Republic of China" (1987).

[3] Frank L. Maraist, Thomas C. Galligan, Jr. \& Gatherine M. Maraist, Maritime Law, West Group, 2003, p.219.

[4] "Maritime Code of the People's Republic of China" (1992).

[5] Si Yuzhuo(2007), "Maritime Law Monograph", Remin University of China Press, p.221

[6] "The No.111 Paper of Civil Judgement" of Guangzhou Maritime Court, 2004. http://www.ccmt.org.cn (2010).

7] "The No.171 Paper of Civil Judgment" of Guangzhou Maritime Court, June, 2003. http://www.ccmt.org.cn (2010).

[8] "Unite Nations Convention on Contracts for the International Carriage of Goods Wholly or Partly by Sea”, United Nations, 2008.

[9] Working Group III of UNCITRAL, 21 ${ }^{\text {th }}$ session, 14-25 January 2008, Vienna:
(1) A/CN.9/645 - Report of Working Group III (Transport Law) on the work of its twenty-first session;

(2) A/CN.9/WG. III/WP.101 - Tranport Law: Draft convention on the carriage of goods [wholly or partly][by sea];

(3) A/CN.9/WG. III/WP.102 - Transport Law: Preparation of a draft convention on the carriage of goods [wholly or partly] [by sea] - Proposal of the delegation of the Netherlands to include "road cargo vehicle" in the defination of "container". http://www.uncitral.org/uncitral/en/commission/ working_groups/3Transport.html (2010)

[10] Working Group III of UNCITRAL, $19^{\text {th }}$ session, $16-27$ April 2007, New York

(1) A/CN.9/WG. II/WP.88 - Transport Law: Preparation of a draft convention on the carriage of goods [wholly or partly] [by sea] - Joint proposal by Australia and France concerning volume contracts.

(2) A/CN.9/WG. III/WP.91 - Transport Law: Praparation of a draft convention on the carriage of goods [wholly or partly] [by sea] - Proposal of the United States of America on carrier and shipper delay. http://www.uncitral.org/uncitral/en/commission/ working_groups/3Transport.html (2010)

[11] Yang Liangyi(2001), "Bill of Lading and other Shipping Documents",China University of Politial Science and Law Press, p.14.

Received 6 February 2012

Revised 28 June 2012

Accepted 29 June 2012 